\author{
Elena NEVEROVA-DZIOPAK ${ }^{1}$ \\ Michał PREISNER ${ }^{2}$
}

\title{
WPLYW TECHNOLOGII OCZYSZCZANIA ŚCIEKÓW NA ICH POTENCJAŁ EUTROFIZUJĄCY
}

\begin{abstract}
Dane statystyczne na temat jakości wód powierzchniowych w okresie 2000-2015 zarówno w Polsce, jak i krajach Unii Europejskiej są alarmujące. Średnio mniej niż $50 \%$ jednolitych części wód w Europie i mniej niż 35\% jednolitych części wód w Polsce osiągnęła nadrzędny cel Ramowej dyrektywy Wodnej - dobrego stanu wód. Bez względu na ogromne inwestycji w zakresie budowy i modernizacji oczyszczalni ścieków komunalnych stan wód pozostawia wiele do życzenia, a eutrofizacja pozostaje priorytetowym problemem we wszystkich krajach. Wspólną cechą, która charakteryzuje ostatnie zmiany w prawodawstwie różnych państw jest zaostrzenie wymagań dotyczących oczyszczonych ścieków komunalnych w związku z pogarszającym się stanem wód powierzchniowych. Te statystyki wskazują, że nadal istnieją duże luki w zakresie ustalania standardów jakości ścieków oczyszczonych i warunków ich wprowadzenia do środowiska, uzasadnionych ekologicznie i ekonomicznie w oparciu o wiedzę i znajomość mechanizmów procesów przebiegających w odbiornikach. W państwach unijnych graniczne wartości ustalone są przeważnie na stężenia azotu ogólnego i fosforu ogólnego, rzadko normowane na inne formy tych pierwiastków w ściekach oczyszczonych. Jednak najbardziej niebezpiecznymi formami substancji biogennych potęgujących proces eutrofizacji, są ich bioprzyswajalne, tj. mineralne formy i ich udział w ściekach oczyszczonych wprowadzanych do odbiornika. Celem niniejszego artykułu jest analiza wpływu technologii oczyszczania ścieków na strukturę zawartości różnych form azotu i fosforu w ściekach oczyszczonych w celu ustalenia ich potencjału eutrofizującego poprzez udział bioprzyswajalnych form substancji biogennych. Badaniom poddano ścieki oczyszczone w nowoczesnych oczyszczalniach „Viikinmaki” w Helsinkach (Finlandia) i „Kujawy” w Krakowie.
\end{abstract}

Słowa kluczowe: ścieki komunalne, technologia oczyszczania, potencjał eutrofizujacy, bioprzyswajalne formy azotu i fosforu.

\footnotetext{
${ }^{1}$ Autor do korespondencji / corresponding author: Elena Neverova-Dziopak, AGH Akademia Górniczo-Hutnicza w Krakowie, Wydział Geodezji Górniczej i Inżynierii Środowiska, Katedra Kształtowania i Ochrony Środowiska, al. Mickiewicza 30, paw. C-4, 30-059 Kraków, elenad@agh.edu.pl

2 Michał Preisner, AGH Akademia Górniczo-Hutnicza w Krakowie, Wydział Geodezji Górniczej i Inżynierii Środowiska, Katedra Kształtowania i Ochrony Środowiska, al. Mickiewicza 30, paw.C-4, 30-059 Kraków, preisner@agh.edu.pl
} 


\section{Wstęp}

Krajowy program oczyszczania ścieków komunalnych [10] jest podstawowym elementem wdrażania postanowień unijnej Dyrektywy Ściekowej 91/271/EWG [2]. Planowane nakłady inwestycyjne na oczyszczanie ścieków komunalnych w Polsce w latach 2000-2015 wynosiły 12,3 mld zł [10]. Miało to przyczynić się do osiągniecia nadrzędnego celu Ramowej Dyrektywy Wodnej - ochrony wód przed zanieczyszczeniem i degradacją, które w roku 2015 w państwach unijnych powinny były osiągnąć stanu co najmniej „dobrego” [2].

Jednak według Raportu Stan Środowiska Przyrodniczego za 2014 rok [4] 4594 wśród ocenionych części jednolitych wód w Polsce (4586 rzek i 10 zbiorników zaporowych) tylko 853 (18\%) osiągnęły stan ,dobry”. Wyniki oceny stanu jezior wskazują, że tylko 403 jednolite części wód jeziornych $(38,8 \%)$ charakteryzują się „dobrym” stanem. Wody przejściowe i przybrzeżne osiągnęły najwyżej stan „umiarkowany”, natomiast stan wód polskiej strefy morza Bałtyckiego w żadnym z akwenów ocenianych pod kątem eutrofizacji nie został oceniony jako dobry [4].

Również w Europie do tej pory stan ponad 50\% wód powierzchniowych jest oceniany ,poniżej dobrego”. Punktowe i rozproszone źródła zanieczyszczeń nadal powodują znaczne presje na środowisko wodne w UE - odpowiednio 38\% oraz $22 \%$. Jednym z głównych zagrożeń dla dobrego stanu wód jest w dalszym ciągu eutrofizacja, spowodowana zbyt dużym ładunkiem substancji biogennych. Nadmiar substancji biogennych występuje w około 30\% części wód w 17 państwach członkowskich, w tym w Polsce [3]. Te statystyki wskazują, że nadal istnieją duże luki w zakresie ustalania standardów jakości ścieków oczyszczonych i warunków ich wprowadzenia do środowiska, uzasadnionych ekologicznie i ekonomicznie w oparciu o wiedzę i znajomość mechanizmów procesów przebiegających w odbiornikach.

Nowoczesne oczyszczalnie mają obowiązek dostosowania się do nowych bardzo restrykcyjnych wymagań, dotyczących zawartości substancji biogennych w ściekach oczyszczonych, ustalonych nieraz na poziomie poniżej wykrywalności/dokładności pomiaru za pomocą nowoczesnej aparatury badawczej. W celu osiągniecia tak restrykcyjnych standardów stosuje się zaawansowane technologie charakteryzujące się dużymi nakładami na energię elektryczną i reagenty chemiczne bez uwzględnienia wiedzy na temat, jakie formy substancji biogennych $\mathrm{w}$ rzeczywistości przez roślinność mogą potęgować procesy eutrofizacji [1]. Należy zauważyć, ze w państwach unijnych normowane są przeważnie stężenia azotu ogólnego i fosforu ogólnego, rzadko ustala się normy na inne formy tych pierwiastków w ściekach oczyszczonych [15]. Jednak najbardziej niebezpiecznymi formami substancji biogennych potęgujących proces eutrofizacji, są ich bioprzyswajalne, $\mathrm{tj}$. mineralne formy $\mathrm{i}$ ich udział $\mathrm{w}$ ściekach oczyszczonych wprowadzanych do odbiornika, warunkujące ,potencjał eutrofizujacy” ścieków. W związku z tym wiedza o zawartości bioprzyswajalnych form azotu i fosforu 
w ściekach wprowadzanych do odbiornika pozwoliłaby na bardziej racjonalny dobór technologii ich oczyszczania dlatego, że zaawansowane technologie głębokiego usuwania biogenów są wyjątkowo drogimi inwestycjami.

Celem niniejszego artykułu jest analiza wpływu technologii oczyszczania ścieków na strukturę zawartości różnych form azotu i fosforu w ściekach oczyszczonych w celu ustalenia ich potencjału eutrofizującego poprzez udział bioprzyswajalnych form substancji biogennych. Badaniom poddano ścieki oczyszczane w nowoczesnych oczyszczalniach „Viikinmaki” w Helsinkach (Finlandia) i „Kujawy” w Krakowie.

\section{Aspekty prawne}

Wymagany stopień redukcji zawartości zanieczyszczeń w ściekach komunalnych, zgodnie z unijną Dyrektywą Ściekową, został ustalony w zależności od wielkości aglomeracji, wyrażonej przez równoważną liczbę mieszkańców (RLM), typu odbiornika ścieków i jego wrażliwości na eutrofizację. Polska, jak i Finlandia zidentyfikowała wszystkie jednolite części wód powierzchniowych jako obszary wrażliwe na eutrofizację [2]. Wymagania dotyczące ścieków komunalnych wprowadzone przez Dyrektywę 91/271/EWG, obowiązujące państwa członkowskie przedstawia tabela 1.

Tabela 1. Wymagania dotyczące ścieków komunalnych odprowadzanych z oczyszczalni do środowiska wodnego na terenie UE (na podstawie [2])

Table 1. Municipal effluent regulations in EU member states (based on [2])

\begin{tabular}{|c|c|c|}
\hline Nazwa wskaźnika & Stężenie, mg/l & $\begin{array}{l}\text { Minimalny procent } \\
\text { redukcji, \% }\end{array}$ \\
\hline $\mathrm{BZT}_{5}$ & 25 & $70-90$ \\
\hline ChZT & 125 & 75 \\
\hline Zawiesiny ogólne & $\begin{array}{c}35 \text { (więcej niż } 10000 \text { RLM) } \\
60 \text { (2 } 000 \text { - } 10000 \text { RLM) }\end{array}$ & $\begin{array}{l}90 \text { (więcej niż } 10000 \text { RLM) } \\
70 \text { (2 } 000 \text { - } 10000 \text { RLM) }\end{array}$ \\
\hline $\begin{array}{l}\text { Fosfor ogólny } \\
\text { (dla obszarów } \\
\text { wrażliwych) }\end{array}$ & $\begin{array}{l}2(10000 \text { - } 100000 \text { RLM) } \\
1 \text { (więcej niż } 10000 \text { RLM) }\end{array}$ & 80 \\
\hline $\begin{array}{l}\text { Azot ogólny } \\
\text { (dla obszarów } \\
\text { wrażliwych) }\end{array}$ & $\begin{array}{l}15 \text { (10 } 000 \text { - } 100000 \text { RLM) } \\
10 \text { (więcej niż } 10000 \text { RLM) }\end{array}$ & $70-80$ \\
\hline
\end{tabular}

Finlandia, jako członek UE oraz kraj-sygnatariusz Konwencji Helsińskiej opiera się w swoim prawodawstwie na normach unijnych, jednak bardzo restrykcyjnie przestrzega zaleceń komisji HELCOM. W Finlandii jakość ścieków 
oczyszczonych jest ustalona przez Rozporządzenie Fińskiego Ministerstwa Środowiska 886 z dnia 12 października 2006 roku (tab. 2) [5].

Tabela 2. Wymagana jakości ścieków oczyszczonych obowiązujące w Finlandii (na podstawie [5])

Table 2. Effluent quality requirements in Finland (based on [5])

\begin{tabular}{|c|c|c|c|}
\hline $\begin{array}{l}\text { Nazwa } \\
\text { wskaźnika }\end{array}$ & $\begin{array}{c}\text { Sposób } \\
\text { oczyszczania/ } \\
\text { RLM }\end{array}$ & $\begin{array}{l}\text { Maksymalne } \\
\text { stężenie, mg/l }\end{array}$ & $\begin{array}{l}\text { Minimalny stopień } \\
\text { redukcji, \% }\end{array}$ \\
\hline $\mathrm{BZT}_{7}$ & \multirow{3}{*}{$\begin{array}{l}\text { Mechaniczno- } \\
\text {-biologiczny }\end{array}$} & 30 & 70 \\
\hline ChZT & & 125 & 75 \\
\hline Zawiesina ogólna & & 35 & 90 \\
\hline \multirow{2}{*}{ Azot ogólny } & $10000-100000$ & 15 & 70 \\
\hline & $>100000$ & 10 & - \\
\hline \multirow{3}{*}{ Fosfor ogólny } & $<2000$ & 3 & 80 \\
\hline & $2000-100000$ & 2 & - \\
\hline & $>100000$ & 1 & - \\
\hline
\end{tabular}

Od 2010 roku HELCOM wprowadziła bardziej restrykcyjne normy zawartości azotu ogólnego i fosforu ogólnego w oczyszczonych ściekach komunalnych. W rekomendacjach HELCOM 28E/5 „Oczyszczanie ścieków komunalnych" zaostrzone wymagania dotyczą oczyszczalni ścieków o RLM > 100000 (tab. 3). Poniższe wymagania miały być zrealizowane stopniowo do końca 2015 roku, co znalazło swoje odzwierciedlenie w jakości ścieków komunalnych oczyszczanych w miejskiej oczyszczalni w Finlandii.

Wymogi Unii Europejskiej dotyczące oczyszczonych ścieków komunalnych znalazły swoje transpozycje do prawodawstwa polskiego w postaci Rozporządzenia Ministra Środowiska z dnia 18 listopada 2014 r. w sprawie warunków, jakie należy spełnić przy wprowadzaniu ścieków do wód lub do ziemi, oraz w sprawie substancji szczególnie szkodliwych dla środowiska wodnego [18]. Graniczne wartości podstawowych wskaźników jakości ścieków przedstawia tabela 4.

Porównanie standardów jakości ścieków pod względem substancji biogennych obowiązujących w Finlandii zgodnie z Rekomendacjami HELCOM 28E/5 i w Polsce zgodnie z obowiązującym Rozporządzeniem przedstawia tabela 5. 
Tabela 3. Graniczne wartości wskaźników jakości ścieków wg nowych rekomendacji HELCOM (na podstawie [6])

Table 3. Limit values of effluent quality according to the new recommendations of HELCOM (based on [6])

\begin{tabular}{|c|c|c|c|}
\hline $\begin{array}{c}\text { Nazwa } \\
\text { wskaźnika }\end{array}$ & RLM & $\begin{array}{l}\text { Maksymalne } \\
\text { stężenie, mg/l }\end{array}$ & $\begin{array}{l}\text { Minimalny stopień } \\
\text { redukcji, \% }\end{array}$ \\
\hline \multirow{3}{*}{$\mathrm{BZT}_{5}$} & $2000-10000$ & 15 & 80 \\
\hline & $10000-100000$ & 15 & 80 \\
\hline & $>100000$ & 15 & 80 \\
\hline \multirow{3}{*}{ Azot ogólny } & $2000-10000$ & - & $\begin{array}{l}30 \text { przy bezpośrednim } \\
\text { zrzucie do morza }\end{array}$ \\
\hline & $10000-100000$ & 15 & $\begin{array}{l}70-80 \text { przy zrzucie } \\
\text { bezpośrednim lub pośrednim } \\
\text { do wód wrażliwych }\end{array}$ \\
\hline & $>100000$ & 10 & $\begin{array}{l}70-80 \text { przy zrzucie } \\
\text { bezpośrednim lub pośrednim } \\
\text { do wód wrażliwych }\end{array}$ \\
\hline \multirow{3}{*}{ Fosfor ogólny } & $2000-10000$ & 1 & $\begin{array}{c}80 \text { przy bezpośrednim } \\
\text { zrzucie do morza }\end{array}$ \\
\hline & $10000-100000$ & 0,5 & $\begin{array}{l}90 \text { przy zrzucie bezpośred- } \\
\text { nim lub pośrednim do morza }\end{array}$ \\
\hline & $>100000$ & 0,5 & $\begin{array}{l}90 \text { przy zrzucie bezpośred- } \\
\text { nim lub pośrednim do morza }\end{array}$ \\
\hline
\end{tabular}

Tabela 4. Graniczne wartości podstawowych wskaźników jakości ścieków zgodnie z aktualnym Rozporządzeniem (na podstawie [18])

Table 4. Sewage quality indicators in accordance with the current Regulation (based on [18])

\begin{tabular}{|c|c|c|c|}
\hline $\begin{array}{c}\text { Nazwa } \\
\text { wskaźnika }\end{array}$ & RLM & $\begin{array}{c}\text { Maksymalne } \\
\text { stężenie, mg/l }\end{array}$ & $\begin{array}{c}\text { Minimalny stopień redukcji, } \\
\text { \% }\end{array}$ \\
\hline \multirow{4}{*}{ Azot ogólny } & $<2000$ & - & - \\
\cline { 2 - 4 } & $2000-9999$ & - & - \\
\cline { 2 - 4 } & $10000-14999$ & 15 & $70-80$ \\
\cline { 2 - 4 } & $15000-99999$ & 15 & $70-80$ \\
\cline { 2 - 4 } & $>100000$ & 10 & - \\
\hline \multirow{4}{*}{$\begin{array}{c}\text { Fosfor } \\
\text { ogólny }\end{array}$} & $2000-9999$ & $\mathrm{n} / \mathrm{n}$ & - \\
\cline { 2 - 4 } & $10000-14999$ & $\mathrm{n} / \mathrm{n}$ & 80 \\
\cline { 2 - 4 } & $15000-99999$ & 2 & 80 \\
\cline { 2 - 4 } & $>100000$ & 2 & 80 \\
\hline
\end{tabular}


Tabela 5. Wymagania dotyczące jakości ścieków oczyszczonych w Finlandii i Polsce (na podstawie $[5,18]$ )

Table 5. Requirements for treated wastewater in Finland and in Poland (based on [5, 18])

\begin{tabular}{|c|c|c|c|c|c|}
\hline \multirow{4}{*}{$\begin{array}{c}\text { Nazwa } \\
\text { wskaźnika }\end{array}$} & RLM & \multicolumn{2}{c|}{$\begin{array}{c}\text { Maksymalne } \\
\text { stężenie, mg/l }\end{array}$} & \multicolumn{2}{c|}{$\begin{array}{c}\text { Minimalny stopień } \\
\text { redukcji, \% }\end{array}$} \\
\cline { 2 - 6 } & Finlandia & Polska & Finlandia & Polska \\
\hline \multirow{4}{*}{ Azot ogólny } & 2000 & - & - & 30 & - \\
\cline { 2 - 6 } & $10000-99999$ & 15 & 15 & $70-80$ & $70-80$ \\
\cline { 2 - 6 } & $>100000$ & 10 & 10 & $70-80$ & $70-80$ \\
\hline \multirow{4}{*}{ Fosfor ogólny } & $2000-9999$ & 1 & - & - & - \\
\cline { 2 - 6 } & $10000-99999$ & 0,5 & 2 & 90 & 80 \\
\cline { 2 - 6 } & $>100000$ & 0,5 & 1 & 90 & 80 \\
\hline
\end{tabular}

\section{Bioprzyswajalność substancji biogennych}

Stan troficzny wód zależy nie tyle od zawartości związków azotu i fosforu w wodzie, ile od ich dostępności dla organizmów roślinnych, która z kolei zależy od całego szeregu czynników. Specyfika mineralnego odżywiania roślinności wodnej nie jest do końca zbadana, ze względu na wysoki stopień komplikacji tych procesów w środowisku wodnym i ich zależności od wielu czynników. Podstawową rolę w rozwoju roślinności wodnej odgrywają mineralne formy azotu i fosforu bezpośrednio przyswajalne przez roślinność $[13,16,17$, 20]. Za najbardziej przyswajalne przez fitoplankton i wyższą roślinność wodną formy związków fosforu uznane są ortofosforany $\mathrm{P}_{-} \mathrm{PO}_{4}[14,19]$. Do najlepiej przyswajalnych form azotu należy azot azotanowy, który dobrze przyswajają niektórzy przedstawiciele gatunku sinic i zielenic. Istnieją gatunki dla których najbardziej odpowiednią formą jest azot amonowy, natomiast najmniej przyswajalną forma jest azot azotynowy [14, 19]. Analiza form specjacyjnych fosforu w wodzie przedstawionych w tabeli 6 pozwala stwierdzić, że nie istnieje dużo bioprzyswajalnych związków fosforu, który w większości przypadków jest uważany za główny czynnik ograniczający eutrofizację.

Informacja i wiedza na temat bioprzyswajalnosci różnych form substancji biogennych może stanowić naukową podstawę opracowania dopuszczalnych wartości fosforu w ściekach oczyszczonych i doboru odpowiednich technologii skutecznych pod względem usuwania form bioprzyswajalnych. 
Tabela 6. Klasyfikacja form fosforu w wodzie (na podstawie [1])

Table 6. Classification scheme od phosphorus in water (based on [1])

\begin{tabular}{|c|c|c|c|}
\hline Formy fosforu & Reaktywność & Bioprzyswajaność & Przykładowe związki \\
\hline \multirow{4}{*}{$\begin{array}{l}\text { Fosfor } \\
\text { mineralny }\end{array}$} & + & + & $\begin{array}{l}\text { Diwodorofosforan wapnia } \\
\qquad \mathrm{CaH}_{2} \mathrm{PO}_{4}\end{array}$ \\
\hline & - & - & $\begin{array}{l}\text { Fosforan glinu } \mathrm{AlPO}_{4} ; \\
\text { Difosforan } \mathrm{P}_{2} \mathrm{O}_{7}^{4-}\end{array}$ \\
\hline & + & - & $\begin{array}{c}\text { Apatyt } \\
\mathrm{Ca}_{3}\left(\mathrm{PO}_{4}\right)_{2}+\left(\mathrm{CaF}_{2}\right) / \mathrm{CaCl}_{2}\end{array}$ \\
\hline & - & + & Tripolifosforany $\mathrm{P}_{3} \mathrm{O}_{10}$ \\
\hline \multirow{2}{*}{$\begin{array}{l}\text { Fosfor } \\
\text { organiczny }\end{array}$} & - & + & ATP, DNA, RNA \\
\hline & - & - & $\begin{array}{c}\text { Kwas fitynowy } \\
\text { (heksafosforan inozytolu ) }\end{array}$ \\
\hline $\begin{array}{l}\text { Fosfor } \\
\text { humusowy }\end{array}$ & + & - & Związki humusowe \\
\hline
\end{tabular}

\section{Charakterystyka badanych obiektów}

\section{Charakterystyka oczyszczalni „Viikinmaki” (Helsinki, Finlandia)}

Na początku lat 90-tych w Helsinkach funkcjonowało 11 oczyszczalni ścieków. W trakcie modernizacji systemu gospodarki wodno-ściekowej ich liczba stopniowo się zmniejszała. W 1994 roku oddano do użytku nową oczyszczalnię ścieków „Viikinmaki” [8]. Lokalizacja oczyszczalni została przedstawiona na rysunku 1.

Do dziś jest to jedna z największych oczyszczalni ścieków w krajach nordyckich, a jej przepustowość wynosi ok. 800000 RLM (270 $000 \mathrm{~m}^{3} /$ dobę) [12]. Obiekt oczyszcza ścieki z Helsinek oraz miejscowości Kerava, Tuusula, Järvenpää i Sipoo. 85\% ścieków dopływających do tej oczyszczalni to są ścieki komunalne, natomiast $15 \%$ to ścieki przemysłowe.

Oczyszczalnia ta jest wyjątkowa w skali światowej ze względu na ulokowanie obiektów technologicznych w skale. Wszystkie z ośmiu linii technologicznych oczyszczalni znajduje się w podziemnych, kamiennych jaskiniach (rys. 2). Ścieki oczyszczone są kierowane do ponad 16-kilometrowego tunelu (rys. 3), którego wylot znajduje się $8 \mathrm{~km}$ od brzegu, na głębokości $20 \mathrm{~m}$ pod poziomem wód Zatoki Fińskiej.

W pozwoleniu wodnoprawnym dla oczyszczalni „Viikinmaki” zakłada się następujące parametry ścieków oczyszczonych: $\mathrm{BZT}_{7}<8 \mathrm{mg} / \mathrm{l}$ (> 95\% redukcji), fosforu ogólnego $<0,3 \mathrm{mg} / \mathrm{l}$ (> $95 \%$ redukcji), azotu ogólnego $<8 \mathrm{mg} / \mathrm{l}$ (70 $-80 \%$ redukcji) [9]. 


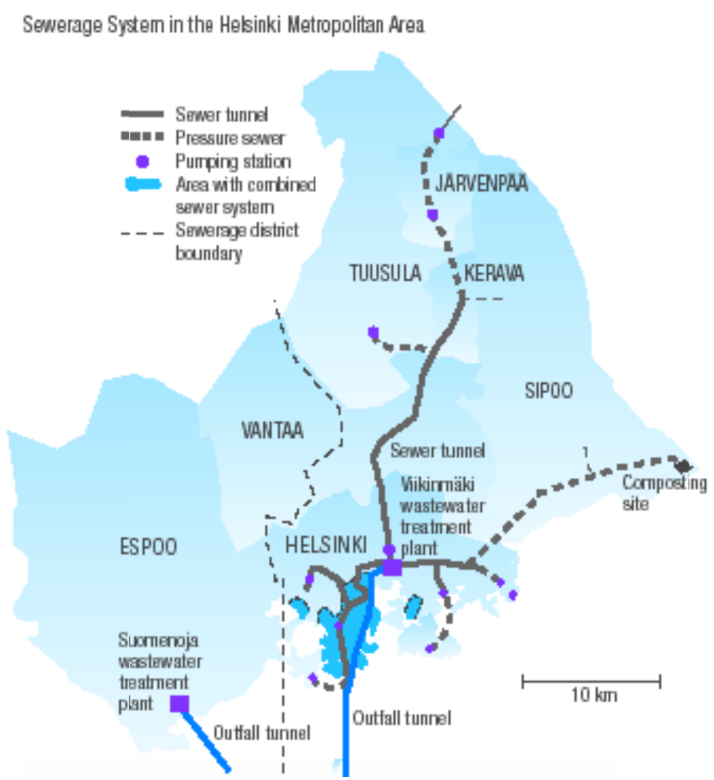

Rys. 1. Lokalizacja oczyszczalni ścieków "Viikinmaki" (na podstawie [9])

Figure 1. Location of wastewater treatment plant "Viikinmaki" (based on [9])

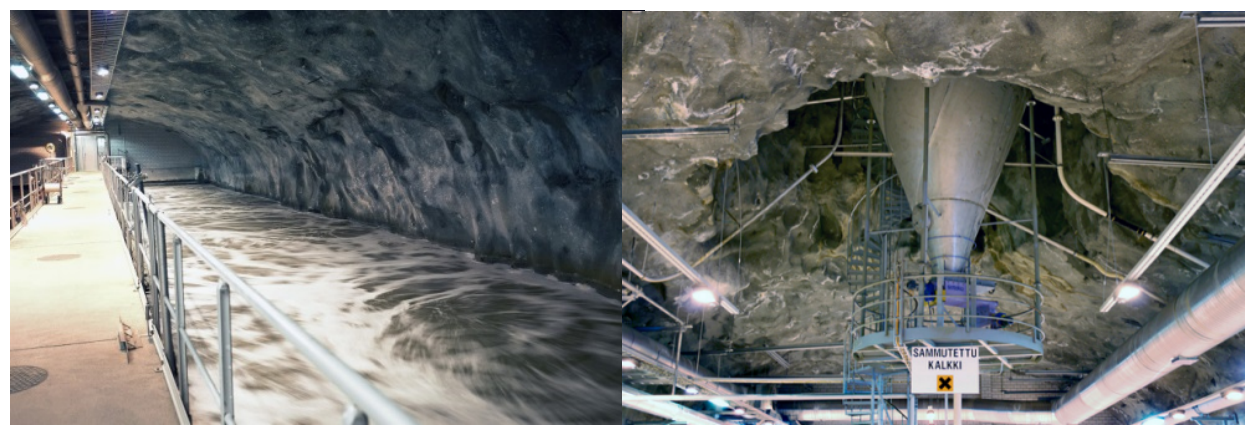

Rys. 2. Wykute w skale obiekty technologiczne oczyszczalni ścieków "Viikinmaki" w Helsinkach (na podstawie [11])

Fig. 2. Hidden in caves technological objects of "Viikinmaki" WWTP in Helsinki (based on [11])

Technologia oczyszczania ścieków składa się z trzech etapów: mechanicznego, biologicznego (osad czynny z nitryfikacja-denitryfikacja) wspomaganego symultanicznym strącaniem fosforu i etapu post-filtracji na filtrach biologicznych. Schemat technologiczny oczyszczalni „Viikinmaki” przedstawia rysunek 4. 


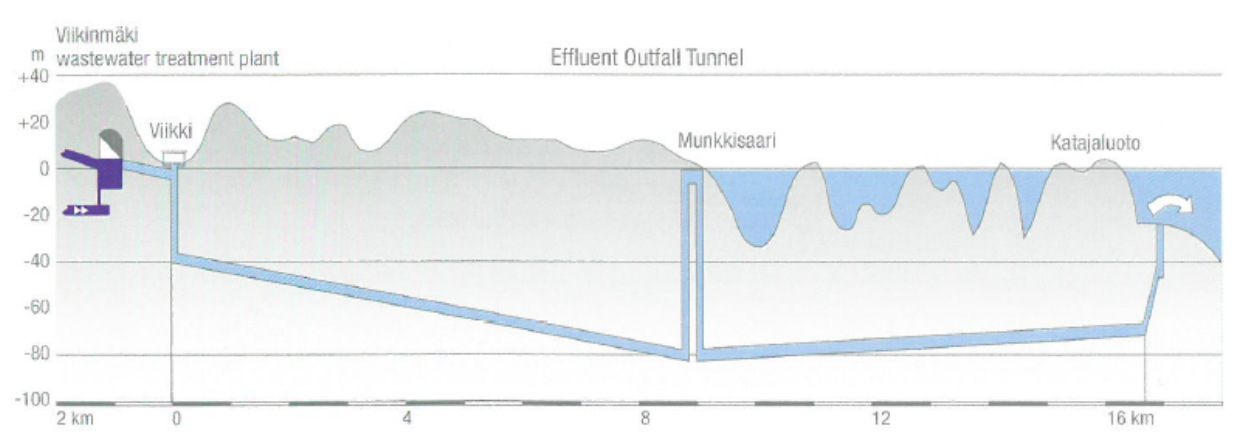

Rys. 3. Profil podłużny tunelu odprowadzającego ścieki z oczyszczalni „Viikinmaki” w Helsinkach (na podstawie [12])

Fig. 3. Profile of the discharge tunnel WWTP "Viikinmaki" in Helsinki (based on [12])

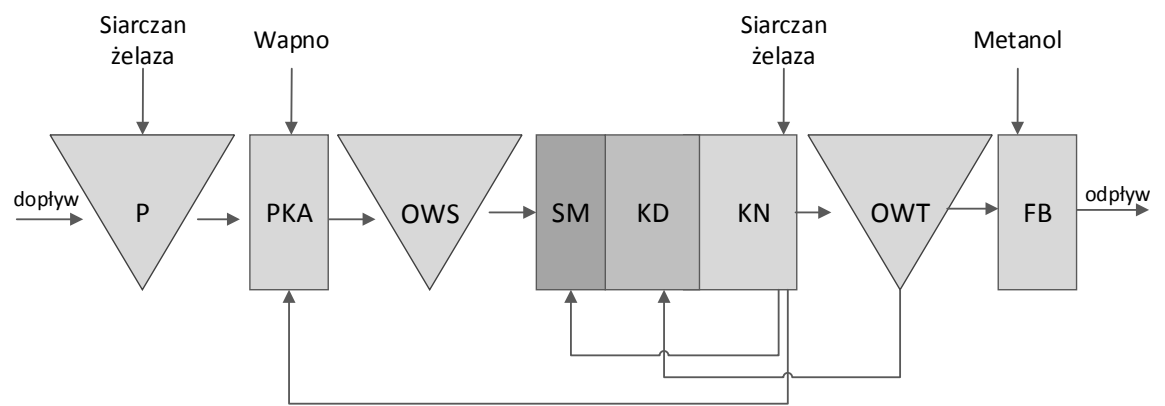

Rys. 4. Schemat technologiczny oczyszczalni ścieków "Viikinmaki" w Helsinkach: P - piaskownik, PKA - komora pre-aeracji, OWS - osadnik wstępny, SM - strefa mieszkania, KD - komora denitryfikacji, KN - komora nitryfikacji, OWT - osadnik wtórny, FB - filtr biologiczny

Fig. 4. Technological scheme of „Viikinmaki” WWTP in Helsinki

\section{Charakterystyka oczyszczalni „Kujawy”}

Oczyszczalnia ścieków „Kujawy” to druga co do wielkości oczyszczalnia w Krakowie. Jej przepustowość w 2013 roku wynosiła 342333 RLM. Planowana jest rozbudowa obiektu do przepustowości 426667 RLM. Obecnie do oczyszczalni dopływa średnio $54900 \mathrm{~m}^{3}$ ścieków na dobę [7], które po oczyszczeniu trafiają do odbiornika - rzeki Wisły. Oczyszczalnia „Kujawy” jest to oczyszczalnia mechaniczno-biologiczna z wzmożonym usuwaniem związków biogennych z możliwością strącania chemicznego fosforu. Lokalizację oczyszczalni przedstawia rysunek 5 .

Obowiązujące do końca 2014 roku pozwolenie wodnoprawne [7] wymagało redukcji BZT5 do $15 \mathrm{mg} / \mathrm{l}$, ChZT do $125 \mathrm{mg} / \mathrm{l}$, zawiesiny ogólnej do $35 \mathrm{mg} / \mathrm{l}$, azotu ogólnego do 22,5 mg/l oraz fosforu ogólnego do 1,5 mg/l. Obecnie obowiązujące pozwolenie jest dostosowane do wymogów narzuconych przez unijną 
dyrektywę ściekową i zakłada zaostrzenie dopuszczalnego stężenia azotu ogólnego do $10 \mathrm{mg} / \mathrm{l}$ oraz fosforu ogólnego do $1 \mathrm{mg} / \mathrm{l}$.

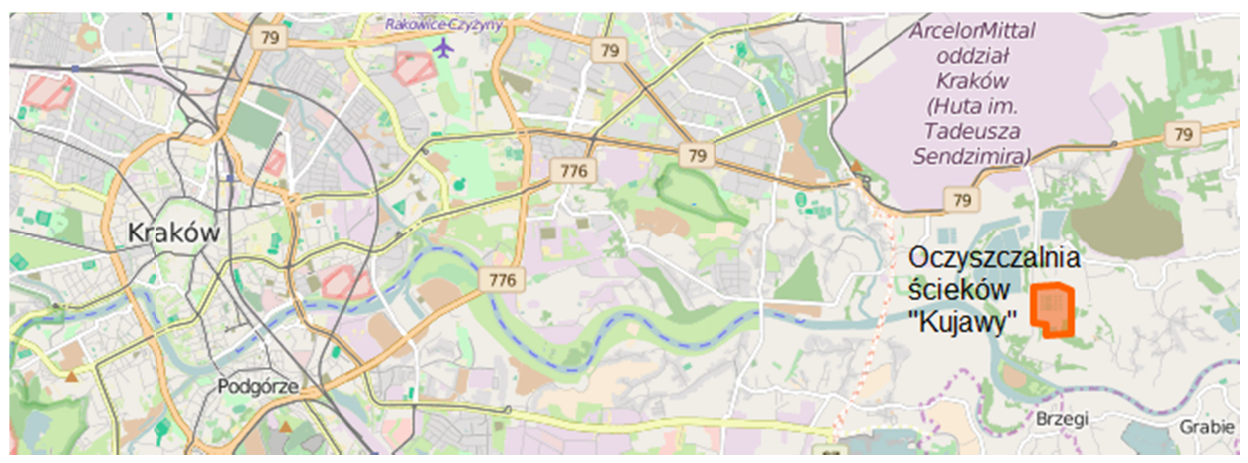

Rys. 5. Lokalizacja oczyszczalni „Kujawy” (na podstawie [7])

Fig. 5. Location of wastewater treatment plant "Kujawy" (based on [7])

Każdy z reaktorów biologicznych to trzyfazowy reaktor $\mathrm{z}$ wydzielonymi fazami: beztlenową, niedotlenioną i tlenową, $z$ wewnętrzną recyrkulacją. Na drodze recyrkulacji osadu (recyrkulacja zewnętrzna) zastosowano komorę predenitryfikacji (rys. 6).

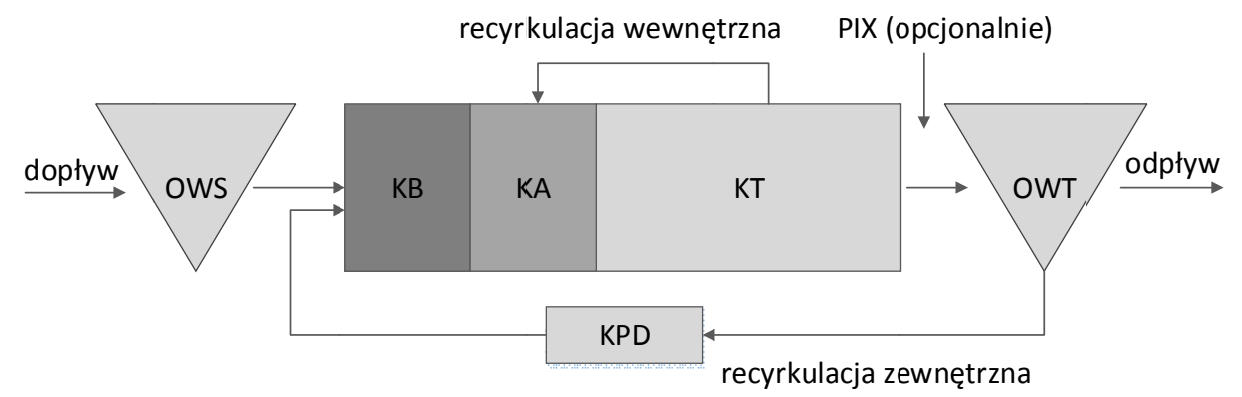

Rysunek 6. Schemat technologiczny oczyszczalni ścieków "Kujawy": Ows - osadnik wstępny, KB - komora beztlenowa, KA - komora anoksyczna, KT - komora tlenowa, OWT - osadnik wtórny, KPD - komora predenitryfikacji

Fig. 6. Technological scheme of „Kujawy” WWTP in Krakow

$\mathrm{Na}$ etapie oczyszczania biologicznego zastosowano reaktory biologiczne, w których prowadzony jest proces niskoobciążonego osadu czynnego w technologii BARDENPHO - zmodyfikowany. Reaktory biologiczne składają się z: 1 komory beztlenowej - cyrkulacyjnej, 2 komór niedotlenionych, 2 komór fakultatywnych (tlenowo niedotlenionych), 4 komór tlenowych i 1 komory predenitryfikacji. Proces prowadzony jest $\mathrm{z}$ zastosowaniem recyrkulacji wewnętrznej i zewnętrznej. W przypadku, gdy w procesie defosfatacji biologicznej nie 
osiąga się wymaganego efektu przewidziano możliwość dodatkowego strącania fosforu z wykorzystaniem siarczanu żelaza (III) jako koagulantu. Oczyszczanie biologiczne kończy sedymentacja osadu w osadnikach wtórnych.

Osad wstępny za pomocą pomp jest kierowany do stacji zagęszczania grawitacyjnego. Osad wtórny nadmierny jest odwadniany, a następnie trafia do wydzielonych zamkniętych komór fermentacyjnych gdzie następuje odzysk biogazu.

\section{Analiza zawartości bioprzyswajalnych form substancji biogennych w badanych oczyszczalniach}

Dane dotyczące jakości ścieków zostały udostępnione przez przedsiębiorstwa zarządzające analizowanymi oczyszczalniami ścieków. Wartości badanych parametrów zostały odpowiednio uporządkowane i przygotowane do przeprowadzenia analizy. Za podstawę posłużyły średnioroczne wartości stężeń różnych form substancji biogennych badanych w okresie lat 2012 - 2014 (Helsinki - „Viikinmaki”) oraz w roku 2013 w krakowskiej oczyszczalni „Kujawy”.

Ponieważ głównym przedmiotem badań była zawartość mineralnych form azotu i fosforu w ściekach oczyszczonych, bezpośrednio przyswajalnych przez roślinność wodną, to kolejnym etapem analizy było określenie struktury zawartości poszczególnych form związków biogennych w ściekach. Analizie poddano ścieki surowe, ścieki po mechanicznym i po biologicznym oczyszczaniu oraz ich transformacji w procesie technologicznym w celu oceny wpływu eutrofizującego ścieków oczyszczonych. Wyniki obliczeń zawartości poszczególnych form azotu i fosforu zostały przedstawione w tabelach 7-9.

Tabela 7. Zawartość związków azotu i fosforu w ściekach surowych

Table 7. Nitrogen and phosphorus forms content in raw wastewater

\begin{tabular}{|c|c|c|c|c|c|c|c|c|}
\hline $\begin{array}{l}\text { Oczyszczalnia / } \\
\text { rok }\end{array}$ & $\begin{array}{l}\mathrm{N}-\mathrm{NH}_{4} \\
\mathrm{mgN} / \mathrm{l}\end{array}$ & $\begin{array}{l}\mathrm{N}-\mathrm{NO}_{2} \\
\mathrm{mgN} / 1\end{array}$ & $\begin{array}{l}\mathrm{N}-\mathrm{NO}_{3} \\
\mathrm{mgN} / \mathrm{l}\end{array}$ & $\begin{array}{l}\mathrm{N} \mathrm{Kj} \\
\mathrm{mgN} / 1\end{array}$ & $\begin{array}{l}\mathrm{N} \text { org. } \\
\mathrm{mgN} / \mathrm{l}\end{array}$ & $\begin{array}{l}\mathrm{N} \text { og. } \\
\mathrm{mgN} / \mathrm{l}\end{array}$ & $\begin{array}{l}\text { P og. } \\
\mathrm{mg} / \mathrm{l}\end{array}$ & $\begin{array}{l}\mathrm{P}^{-} \mathrm{PO}_{4} \\
\mathrm{mg} / \mathrm{l}\end{array}$ \\
\hline Helsinki 2012 r. & 31,37 & 0 & 0 & 43,15 & 11,77 & 43,15 & 5,852 & 2,8 \\
\hline Helsinki 2013 r. & 37,17 & 0 & 0 & 47,6 & 10,42 & 47,6 & 6,457 & 3,225 \\
\hline Helsinki 2014 r. & 37,3 & 0 & 0,025 & 50,55 & 13,25 & 50,57 & 6,922 & 3,225 \\
\hline Kujawy 2013 r. & 47,26 & 0,02 & 0,13 & 67,54 & 20,28 & 67,65 & 6,60 & 3,71 \\
\hline
\end{tabular}

\subsection{Struktura zawartości form azotu $w$ ściekach}

\section{Oczyszczalnia ścieków „Viikinmaki” w Helsinkach}

Oczyszczalnia ścieków spełnia wymagania prawne dotyczące zawartości związków biogennych w ściekach oczyszczonych. Średnie stężenia azotu ogól- 
nego i fosforu ogólnego w ściekach oczyszczonych w analizowanym okresie wynosiły odpowiednio $4,37 \mathrm{mgN} / \mathrm{l}$ i $0,22 \mathrm{mgP} / \mathrm{l}$.

Tabela 8. Zawartość związków azotu i fosforu w ściekach po etapie mechanicznym

Table 8. Nitrogen and phosphorus forms content in wastewater after mechanical treatment

\begin{tabular}{|c|c|c|c|c|c|c|c|c|}
\hline $\begin{array}{c}\text { Oczyszczalnia / } \\
\text { rok }\end{array}$ & $\begin{array}{c}\mathrm{N}-\mathrm{NH}_{4} \\
\mathrm{mgN} / 1\end{array}$ & $\begin{array}{c}\mathrm{N}_{\mathrm{NO}} \mathrm{N}_{2} \\
\mathrm{mgN} / 1\end{array}$ & $\begin{array}{c}\mathrm{N}_{\mathrm{NO}} \\
\mathrm{mgN} / \mathrm{l}\end{array}$ & $\begin{array}{c}\mathrm{N} \mathrm{Kj} \\
\mathrm{mgN} / 1\end{array}$ & $\begin{array}{c}\mathrm{N} \text { org. } \\
\mathrm{mgN} / \mathrm{l}\end{array}$ & $\begin{array}{c}\mathrm{N} \text { og. } \\
\mathrm{mgN} / \mathrm{l}\end{array}$ & $\begin{array}{c}\mathrm{P} \text { og. } \\
\mathrm{mg} / \mathrm{l}\end{array}$ & $\begin{array}{c}\mathrm{P}_{\mathrm{PO}} \\
\mathrm{mg} / \mathrm{l}\end{array}$ \\
\hline Helsinki 2012 r. & 35,17 & 0 & 12,15 & $\mathrm{~b} / \mathrm{d}$ & $\mathrm{b} / \mathrm{d}$ & $\mathrm{b} / \mathrm{d}$ & $\mathrm{b} / \mathrm{d}$ & 0,2 \\
\hline Helsinki 2013 r. & 41,05 & 0 & 12,77 & $\mathrm{~b} / \mathrm{d}$ & $\mathrm{b} / \mathrm{d}$ & $\mathrm{b} / \mathrm{d}$ & $\mathrm{b} / \mathrm{d}$ & 0,2 \\
\hline Helsinki 2014 r. & 40,4 & 0 & 14,07 & $\mathrm{~b} / \mathrm{d}$ & $\mathrm{b} / \mathrm{d}$ & $\mathrm{b} / \mathrm{d}$ & $\mathrm{b} / \mathrm{d}$ & 0,2 \\
\hline Kujawy 2013 r. & 60,63 & 0 & 0,14 & 81,77 & 21,13 & 81,93 & 8,68 & 6,33 \\
\hline
\end{tabular}

b/d - brak danych

Tabela 9. Zawartość związków azotu i fosforu w ściekach biologicznie oczyszczonych

Table 9. Nitrogen and phosphorus forms content in biologically treated wastewater

\begin{tabular}{|c|c|c|c|c|c|c|c|c|}
\hline $\begin{array}{c}\text { Oczyszczalnia / } \\
\text { rok }\end{array}$ & $\begin{array}{c}\mathrm{N}-\mathrm{NH}_{4} \\
\mathrm{mgN} / 1\end{array}$ & $\begin{array}{c}\mathrm{N}-\mathrm{NO}_{2} \\
\mathrm{mgN} / 1\end{array}$ & $\begin{array}{c}\mathrm{N}^{-\mathrm{NO}_{3}} \\
\mathrm{mgN} / 1\end{array}$ & $\begin{array}{c}\mathrm{N} \mathrm{Kj} \\
\mathrm{mgN} / 1\end{array}$ & $\begin{array}{c}\mathrm{N} \text { org. } \\
\mathrm{mgN} / 1\end{array}$ & $\begin{array}{c}\mathrm{N} \text { og. } \\
\mathrm{mgN} / 1\end{array}$ & $\begin{array}{c}\text { P og. } \\
\mathrm{mg} / \mathrm{l}\end{array}$ & $\begin{array}{c}\mathrm{P}_{\mathrm{PO}} \mathrm{PO}_{4} \\
\mathrm{mg} / \mathrm{l}\end{array}$ \\
\hline Helsinki 2012 r. & 1,775 & $\mathrm{~b} / \mathrm{d}$ & 1,275 & 3,875 & 2,1 & 5,15 & 0,225 & 0,1 \\
\hline Helsinki 2013 r. & 0,9 & $\mathrm{~b} / \mathrm{d}$ & 1,225 & 2,3 & 1,4 & 3,525 & 0,207 & 0,1 \\
\hline Helsinki 2014 r. & 1,05 & $\mathrm{~b} / \mathrm{d}$ & 1,875 & 2,55 & 1,5 & 4,425 & 0,22 & 0,1 \\
\hline Kujawy 2013 r. & 10,80 & 0,77 & 5,29 & 11,84 & 1,03 & 17,52 & 0,37 & 0,20 \\
\hline
\end{tabular}

b/d - brak danych

Analiza struktury zawartości różnych form azotu w ściekach surowych dopływających do oczyszczalni „Viikinmaki” w Helsinkach oparta na danych monitoringu ich jakości w okresie lat 2012 - 2014 pokazała, że głównymi formami jest azot amonowy (75\%) i azot organiczny (25\%), przy braku azotynów i azotanów. W ściekach oczyszczonych biologicznie brak azotynów, a udział azotu organicznego stanowi średnio 38\%, azotu azotanowego - 34\% i azotu amonowego - $28 \%$.

\section{Oczyszczalnia ścieków „Kujawy” w Krakowie}

Oczyszczalnia spełniła wymogi dotyczące zawartości związków biogennych w ściekach oczyszczonych obowiązujące w 2013 roku. Średnie stężenia azotu ogólnego i fosforu ogólnego w ściekach oczyszczonych w analizowanym okresie wynosiły odpowiednio $17,52 \mathrm{mgN} / \mathrm{l}$ i $0,37 \mathrm{mgP} / \mathrm{l}$.

Analiza zawartości różnych form związków azotu w ściekach oczyszczanych w oczyszczalni „Kujawy” została przeprowadzona na podstawie danych monitoringu w roku 2013. Pozwoliła ona stwierdzić, że główną formą azotu 
w ściekach surowych jest azot amonowy (ok. 70\%) oraz azot organiczny (ok. 30\%) i nieznaczne ilości azotynów i azotanów ( nieco ponad 1\%).

Po etapie mechanicznego oczyszczania zawartość azotu amonowego znacząco wzrasta o $28 \%$, co skutkuje wzrostem zawartości azotu ogólnego odpowiednio o $21 \%$. W ściekach biologicznie oczyszczonych udział różnych form azotu w badanym okresie wynosił odpowiednio: azot organiczny $-6 \%$, azot azotanowy $-30 \%$ i azot amonowy $-62 \%$.

Wyniki analizy porównawczej zawartości bioprzyswajalnych form azotu przedstawiono w tabeli $10 \mathrm{i}$ na rysunku 7.

Tabela 10. Udział poszczególnych form azotu w ściekach surowych i oczyszczonych

Table 10. Nitrogen and phosphorus content in raw and biologically treated wastewater

\begin{tabular}{|c|c|c|c|c|c|}
\hline \multicolumn{7}{|c|}{ Ścieki surowe } \\
\hline $\begin{array}{c}\text { Oczyszczalnia / } \\
\text { Rok }\end{array}$ & $\begin{array}{c}\text { N og. } \\
\mathrm{mgN} / 1\end{array}$ & $\begin{array}{c}\text { N org. } \\
\mathrm{mgN} / 1\end{array}$ & $\begin{array}{c}\mathrm{N} \text { min. } \\
\mathrm{mgN} / \mathrm{l}\end{array}$ & $\begin{array}{c}\text { N org./ } \\
\mathrm{N} \text { min. }\end{array}$ & $\begin{array}{c}\text { \% zawartości } \\
\text { bioprzyswajalnego } \\
\mathrm{N}\end{array}$ \\
\hline Helsinki & 47,11 & 11,82 & 35,29 & 0,34 & $74,87 \%$ \\
\hline „Kujawy” & 67,65 & 20,28 & 47,39 & 0,43 & $70,05 \%$ \\
\hline \multicolumn{7}{|c|}{ Ścieki oczyszczone } \\
\hline $\begin{array}{c}\text { Oczyszczalnia / } \\
\text { Rok }\end{array}$ & $\begin{array}{c}\mathrm{N} \text { og. } \\
\mathrm{mgN} / 1\end{array}$ & $\begin{array}{c}\text { N org. } \\
\mathrm{mgN} / 1\end{array}$ & $\begin{array}{c}\mathrm{N} \text { min. } \\
\mathrm{mgN} / 1\end{array}$ & $\begin{array}{c}\mathrm{N} \text { org./ } \\
\mathrm{N} \text { min. }\end{array}$ & $\begin{array}{c}\text { \% zawartości } \\
\text { biopryswajalnego } \\
\mathrm{N}\end{array}$ \\
\hline Helsinki & 4,37 & 1,67 & 2,70 & 0,62 & $61,87 \%$ \\
\hline „Kujawy” & 17,52 & 1,03 & 16,10 & 0,06 & $91,87 \%$ \\
\hline
\end{tabular}

Analiza zawartości udziału procentowego sumy bioprzyswajalnych (mineralnych) form azotu w ściekach surowych pozwala wnioskować, że ścieki dopływające $\mathrm{z}$ aglomeracji Helsinki charakteryzują się nieco wyższym udziałem bioprzyswajalnego azotu (ok. 75\%) niż ścieki dopływające do oczyszczalni z aglomeracji krakowskiej (ok. 70\%), co nie stanowi istotnej różnicy.

Natomiast w ściekach po oczyszczaniu biologicznym odprowadzanych z oczyszczalni „Viikinmaki” udział bioprzyswajalnych form azotu wynosi ok. 62\%, a w ściekach oczyszczonych w OŚ „Kujawy” udział ten wynosi aż 92\%. Przy czym ścieki z OŚ „Kujawy” charakteryzują się bardzo niską zawartością azotu organicznego i bardzo wysoką zawartością azotu amonowego i dość wysoką zawartością azotu azotanowego.

W ściekach odpływających w oczyszczalni „Viikinmaki” wszystkie trzy formy mineralnego azotu zawarte są $\mathrm{w}$ zbliżonych proporcjach $\mathrm{z}$ przewagą azotu organicznego. Porównując procent zawartości bioprzyswajalnych form azotu w ściekach surowych i oczyszczonych można zauważyć, że w ściekach oczysz- 
czonych w OŚ „Viikinmaki” ich udział zmniejszył się o 17\%, natomiast w ściekach oczyszczonych z OŚ „Kujawy” udział form bioprzyswajalnych wzrósł o $24 \%$ (rys. 7 ).

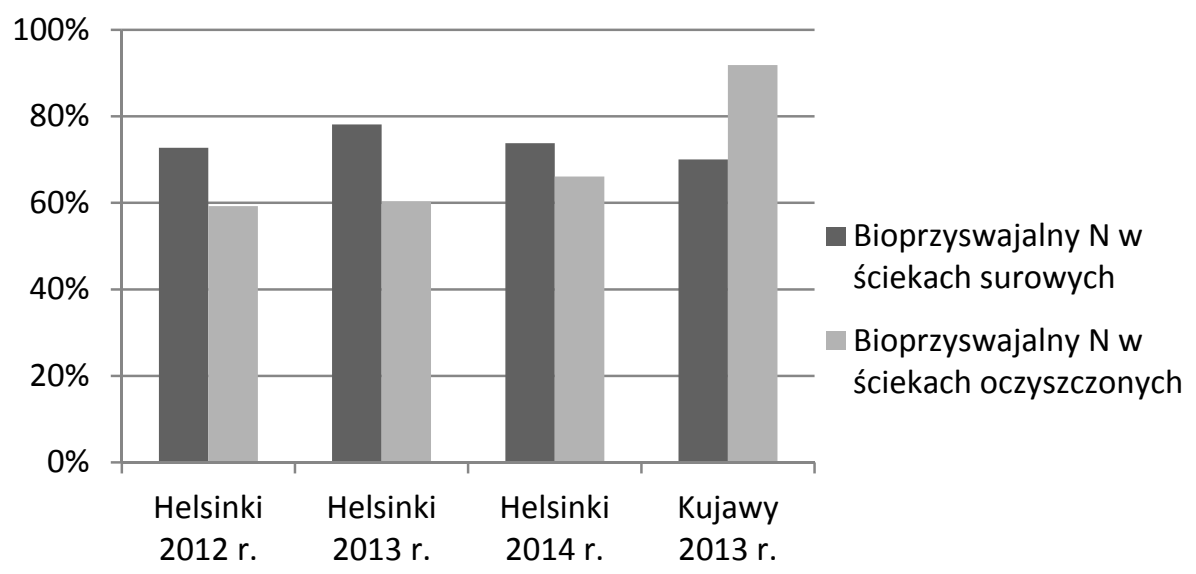

Rys. 7. Zawartość bioprzyswajalnych form azotu w ściekach surowych i oczyszczonych (suma $\mathrm{N}-\mathrm{NO}_{3}, \mathrm{~N}-\mathrm{NO}_{2}$ i N-NH )

Fig. 7. Content of bioavailable nitrogen compounds in raw and treated wastewater (the sum of $\mathrm{N}-\mathrm{NO}_{3}, \mathrm{~N}-\mathrm{NO}_{2}$ i N-NH 4

\subsection{Struktura zawartości form fosforu w ściekach}

\section{Oczyszczalnia ścieków ,Viikinmaki” w Helsinkach}

Fosfor w ściekach surowych dopływających do oczyszczalni w Helsinkach występuje w postaci fosforu organicznego (52\%) i fosforanów (48\%). Po etapie mechanicznego oczyszczania i wstępnym strącaniu zawartość fosforanów zmniejsza się o 92,8\%, a po biologicznym oczyszczaniu i strącaniu symultanicznym - o 96,4\%. Udział fosforu organicznego i fosforanów w ściekach oczyszczonych wynosi odpowiednio $54,5 \%$ i 45,5\%.

\section{Oczyszczalnia ścieków „Kujawy” w Krakowie}

Na zawartość fosforu w dopływie do oczyszczalni „Kujawy” składają się w 56\% fosfor fosforanowy i w $44 \%$ fosfor organiczny. Po mechanicznym oczyszczaniu zawartość fosforanów zwiększą się do 73\%, a zawartość fosforu organicznego wynosi $27 \%$. W ściekach biologicznie oczyszczonych $54 \%$ fosforu w odpływie stanowiły fosforany, a pozostałe $46 \%$ fosfor organiczny.

Wyniki analizy porównawczej zawartości poszczególnych form fosforu przedstawia tabela 11. 
Tabela 11. Formy fosforu w ściekach surowych i oczyszczonych

Table 11. Compounds of phosphorus in raw and treated wastewater

\begin{tabular}{|c|c|c|c|c|c|}
\hline \multicolumn{7}{|c|}{ Ścieki surowe } \\
\hline $\begin{array}{c}\text { Oczyszczalnia } \\
\text { / Rok }\end{array}$ & $\begin{array}{c}\text { P og. } \\
\mathrm{mg} / 1\end{array}$ & $\begin{array}{c}\text { P org. } \\
\mathrm{mgP} / 1\end{array}$ & $\begin{array}{c}\text { P min. } \\
\mathrm{mgP} / 1\end{array}$ & $\begin{array}{c}\text { P org./ } \\
\text { P min. }\end{array}$ & $\begin{array}{c}\text { \% zawartości } \\
\text { bioprzyswajalnego } \\
\text { P }\end{array}$ \\
\hline Helsinki & 6,411 & 3,328 & 3,083 & 1,08 & $48,12 \%$ \\
\hline „Kujawy” & 6,599 & 3,233 & 3,705 & 0,87 & $56,14 \%$ \\
\hline \multicolumn{7}{|c|}{ Ścieki oczyszczone } \\
\hline Oczyszczalnia & P og. & $\begin{array}{c}\text { P org. } \\
\text { mg/l }\end{array}$ & $\begin{array}{c}\text { P min. } \\
\text { mg/l }\end{array}$ & $\begin{array}{c}\text { P org./ } \\
\text { P min. }\end{array}$ & $\begin{array}{c}\text { \% zawartości } \\
\text { bioprzyswajalnego } \\
\text { P }\end{array}$ \\
\hline Helsinki & 0,218 & 0,118 & 0,100 & 1,17 & $46,03 \%$ \\
\hline „Kujawy” & 0,373 & 0,172 & 0,201 & 0,85 & $53,93 \%$ \\
\hline
\end{tabular}

Średni udział bioprzyswajalnych form fosforu (fosforanów) w ściekach surowych dopływających do oczyszczalni „Kujawy” jest tylko o $8 \%$ większy, niż w ściekach z aglomeracji Helsinek. Taka sama różnica charakteryzuje i ścieki oczyszczone (rys. 8).

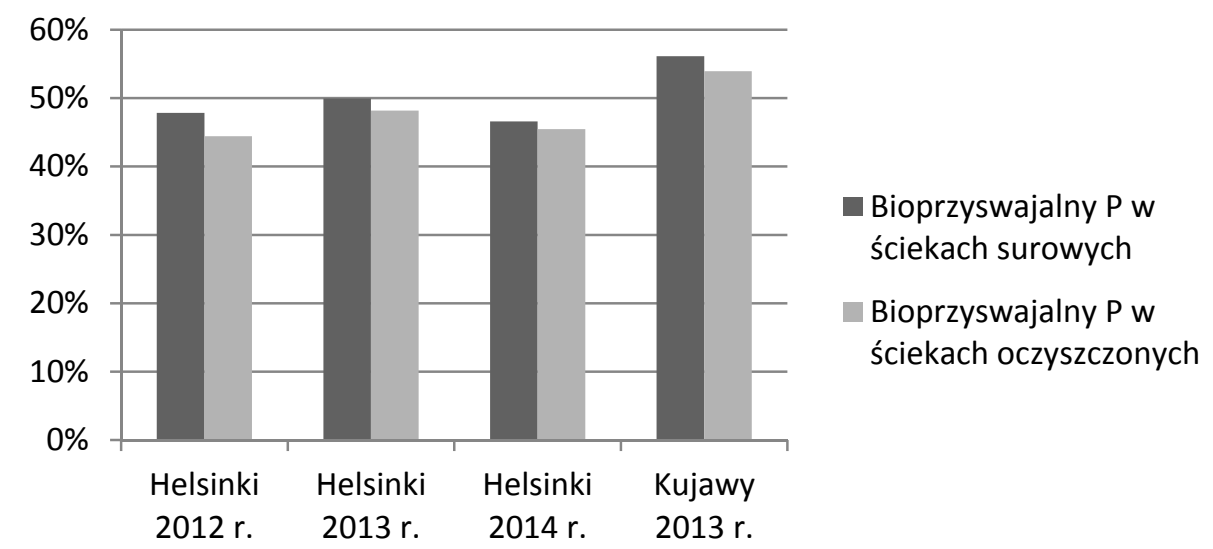

Rys. 8. Zawartość bioprzyswajalnych form fosforu w ściekach surowych i oczyszczonych

Fig. 8. Content of bioavailable phosphorus compounds in raw and treated wastewater

Efektywność usuwania związków biogennych w badanych technologiach z uwzględnieniem udziału bioprzyswajalnych form azotu i fosforu przedstawia tabela 12 . 
Tabela 12. Porównanie efektywności usuwanie związków azotu i fosforu

Table 12. Comparison of efficiency of removal of nitrogen and phosphorus

\begin{tabular}{|c|c|c|}
\hline Oczyszczalnia ścieków & ,Viikinmaki” & ,Kujawy” \\
\hline Technologia oczyszczania & $\begin{array}{c}\text { Osad czynny z nitryfikacją } \\
\text { i denitryfikacją } \\
\text { + symultaniczne strącanie } \\
\text { P } \\
\text { + filtry biologiczne }\end{array}$ & $\begin{array}{c}\text { BARDENPHO } \\
\text { + opcjonalne strącanie P }\end{array}$ \\
\hline Efektywność usuwania N og. & $90,73 \%$ & $74,10 \%$ \\
\hline Zawartość bioprzswajalnego N & $74,87 \%$ & $70,05 \%$ \\
\hline Efektywność usuwania P og. & $96,61 \%$ & $94,34 \%$ \\
\hline Zawartość bioprzswajalnego P & $61,87 \%$ & $91,87 \%$ \\
\hline
\end{tabular}

\section{Wnioski}

1. Informację na temat stanu wód powierzchniowych i dane statystyczne zawarte $w$ raportach na temat stanu środowiska wodnego w państwach unijnych i Polsce wskazują, że nadal istnieją duże luki w zakresie ustalania standardów jakości ścieków oczyszczonych i warunków ich wprowadzenia do środowiska, które byłyby uzasadnione ekologicznie i ekonomicznie w oparciu o wiedzę i znajomość mechanizmów procesów przebiegających w odbiornikach.

2. Wysokość kosztów inwestycji w zakresie oczyszczania ścieków w Polsce w latach 2000-2015 jest niewymierna do niskiego poziomu uzyskanych efektów poprawy stanu jednolitych części wód.

3. Założenie Ramowej Dyrektywy Wodnej o osiągnięciu co najmniej dobrego stanu wszystkich jednolitych części wód w krajach należących do Unii Europejskiej okazało się nieco utopijne. Cel ten został osiągnięty średnio dla 40\% wód w obszarze UE.

4. Analiza wymagań dotyczących jakości ścieków oczyszczonych w różnych krajach pod względem zawartości substancji biogennych pozwala wnioskować, że w prawodawstwie większości państw unijnych nie bierze się pod wagę zawartości mineralnych form azotu i fosforu, które są bezpośrednio przyswajalne dla roślinności wodnej i natychmiast włączają się w procesy rozwoju roślinności wodnej.

5. Stan troficzny wód zależy nie tyle od zawartości związków azotu i fosforu w wodzie, ile od ich dostępności dla organizmów roślinnych, która z kolei zależy od całego szeregu czynników. W związku z tym, wpływ oczyszczonych ścieków na rozwój procesów eutrofizacji w dominującym stopniu uwarunkowany jest zawartością przyswajalnych form azotu i fosforu w ściekach oraz warunków panujących w odbiornikach. 
6. Analiza aktów prawnych reglamentujących jakość oczyszczonych ścieków w dwóch państwach unijnych, Finlandii i Polski, bazujących na unijnej dyrektywie ściekowej, pozwoliła jednak na dostrzeżenie dość znacznych różnic w krajowych normatywach jakości ścieków oczyszczonych. Finlandia posiada znacznie bardziej rygorystyczne wymagania pod względem stężeń fosforu ogólnego dla oczyszczalni ścieków o dużej przepustowości niż Polska. W odróżnieniu od Polski, w Finlandii są ustalone również dość ostre normatywy zawartości substancji biogennych dla oczyszczalni o małej przepustowości, zaś w Polsce nie są one normowane dla takich obiektów.

7. Analiza porównawcza efektywności usuwania biogenów w dwóch badanych nowoczesnych oczyszczalniach pokazała, że oba obiekty spełniają zarówno wymagania zawarte w odpowiednich Rozporządzeniach krajowych oraz pozwoleniach wodnoprawnych i charakteryzują się wysokim stopniem redukcji azotu ogólnego i fosforu ogólnego na poziomie wymagań dyrektywy ściekowej UE.

8. Efektywność usuwania azotu ogólnego w oczyszczalni „Viikinmaki” (90,7\%) znacznie przekracza efektywność usuwania azotu ogólnego w oczyszczalni „Kujawy” (74\%), przy czym ścieki oczyszczone w oczyszczalni „Viikinmaki" zawierają znacznie mniej bioprzyswajalnych form azotu (62\% i $92 \%$ odpowiednio).

9. Efektywność usuwania fosforu ogólnego w obu oczyszczalniach była wysoka („Viikinmaki” - 97\%; „Kujawy”-95\%), natomiast zawartość bioprzyswajalnego fosforu w odpływie z oczyszczalni „Viikinmaki” była znacznie niższa, niż z odpływie z oczyszczalni „Kujawy” (62\% i $92 \%$ odpowiednio).

10.W wyniku przeprowadzonej analizy okazało się, że technologia oczyszczania ścieków w Helsinkach oparta na metodzie osadu czynnego z nitryfikacjądenitryfikacją, symultanicznym strącaniem fosforu oraz biologiczną postfiltracją okazuje się być bardziej efektywna pod względem zapobiegania eutrofizacji, niż technologia $\mathrm{z}$ zaawansowanym biologicznym usuwaniem związków azotu i fosforu oraz strącaniem fosforanów, stosowana w oczyszczalni „Kujawy”.

11.Zaawansowane technologie głębokiego usuwania biogenów są wyjątkowo drogimi inwestycjami, których celem jest zapobieganie rozwoju procesu eutrofizacji w odbiornikach. Głównym czynnikiem eutrofizacji jest zawartość w ściekach oczyszczonych takich form substancji biogennych, które są bezpośrednio przyswajalne przez roślinność wodną. W związku z tym wiedza o zawartości bioprzyswajalnych form azotu i fosforu w ściekach wprowadzanych do odbiornika pozwoliłaby na uzasadniony pod względem ekologicznym i ekonomicznym dobór technologii ich oczyszczania. 


\section{Literatura}

[1] Brett M.T., Li B.: Alternatives to bioassays for effluent phosphorus measurement. The Bioavailable Phosphorus (BAP) Fraction in Effluent from Advanced Secondary and Tertiary Treatment (NUTR1R06m). Executive Summary. WERF Water Environment Research Foundation, www.werf.org.

[2] Council Directive 91/271/EEC of 21 May 1991 concerning urban waste-water treatment.

[3] European Environment Agency: The European environment - state and outlook 2015. Synthesis Report. EEA, 2015.

[4] Główny Inspektorat Ochrony Środowiska: Stan środowiska przyrodniczego w Polsce. Raport 2014, Biblioteka Monitoringu Środowiska, Warszawa 2014.

[5] Government Decree on Urban Waste Water Treatment 888/2006 Issued in Helsinki 12 October 2006.

[6] HELCOM Recommendation 28E/5 Municipal wastewater treatment, HELCOM Baltic Sea Action Plan adopted on 15 November 2007 in Krakow, Poland by the HELCOM Extraordinary Ministerial Meeting.

[7] http://wodociagi.krakow.pl/o-firmie/oczyszczalnia-Kujawy.html

[8] http://www.da-voda.com/vodogalereya/chistaya-voda-s-izyuminkoj-samye-neoby chnye-ochistnye-sooruzheniya-v-mire/Viiki

[9] http:// www.helcom.fi/ Documents/ Action\%20areas/ Industrial \%20releases/17_ M.pdf.

[10] .http://www.kzgw.gov.pl/pl/Krajowy-program-oczyszczania-sciekow-komunalnyc h.html.

[11] https://www.flickr.com/photos/sameli/sets/72157607704932823/.

[12] https://www.hsy.fi/en/experts/water-services/wastewater-treatment-plants/Viikinma ki/Pages/default.aspx.

[13] Likens G.E.: River Ecosystem Ecology: A Global Perspective.; Academic Press, Mar 29, 2010, 424 pages, ISBN 0123819997, 9780123819994 from: https://books.google.pl/books?id=v5VHWWrK_SsC\&printsec=frontcover\&source $=$ gbs_ge_summary_r\&cad $=0 \# \mathrm{v}=$ onepage $\& \mathrm{q} \& \mathrm{f}=$ false.

[14] Materiały Instytutu Biologii wód wewnętrznych Rosyjskiej Akademii Nauk: Pierwicznajaprodukcja, mineralnojepitanie, krugoworot osnownych biogennych elementow, from http://ibiw.ru/index.php?p=edu/eco/eco2.

[15] Neverova-Dziopak E., Preisner M.: Analiza metod ustalania warunków wprowadzania ścieków komunalnych do odbiorników w wybranych państwach, Ochrona Środowiska, vol. 37, No. 1, Wrocław 2015, pp. 3-9.

[16] Oliver R.L., Boon P.I.: Bioavailability of nutrients in turbid waters, MurrayDarling Freshwater Research Centre, 1992, from: http://arrow.latrobe.edu.au:8080/ vital/access/manager/Repository/latrobe:33684;jsessionid=BD76B90584303CDE E3D8B0AC6736A7CC.

[17] Pehlivanoglu E., Sedlak D.L.: Bioavailability of wastewater-derived organic nitrogen to the alga Selenastrum Capricornutum. Water Research, vol. 38, Issues 14-15, August-September 2004, Pages 3189-3196, doi:10.1016/j.watres.2004.04.027. 
[18] Rozporządzenie Ministra Środowiska z dnia 18 listopada 2014 r. w sprawie warunków, jakie należy spełnić przy wprowadzaniu ścieków do wód lub do ziemi, oraz w sprawie substancji szczególnie szkodliwych dla środowiska wodnego (Dz. U. 2014 poz. 1800).

[19] Sadczykov A.P., Kudriaszov M.A.: Ekologia przybrzeżno-wodnojrastitelnosti. M.: W-wo NIA-Priroda, REFIA, Moskwa 2004. - 220 c., ISBN 5-7844-0107-6, from: http://ecopolis kosino.narod.ru/olderfiles/1/SADCHIKOV_eco_vod_rast.pdf.

[20] Schwartz M.: Encyclopedia of Coastal Science. Springer Science \& Business Media, Nov 8, 2006, 1211 pages, ISBN 1402038801, 9781402038808.

\section{THE IMPACT OF WASTEWATER TREATMENT TECHNOLOGY ON THEIR EUTROPHICATION POTENTIAL}

\section{S u m m a r y}

The statistics on surface water quality in the period 2000-2015, in Poland and European Union are alarming. On average, less than $50 \%$ of water bodies in Europe and not less than $35 \%$ in Poland reached the primary aim of Water Framework Directive - good water status. Regardless of the fact that huge investments in the construction and modernization of wastewater treatment plants water status has not improved enough and eutrophication remains a priority issue in all countries. A common feature that characterizes the recent changes in the legislation of different countries are tightening requirements for treated wastewater treatment due to deteriorating surface water quality. These statistics indicate that there are still large gaps in the setting of quality standards for effluent and the conditions of their discharge, environmentally and economically reasonable based on the knowledge and understanding the mechanisms of processes occurring in wastewater receivers. In EU countries limits are set mostly on the concentration of total nitrogen and total phosphorus. Rarely there are standardized other forms of these elements in the treated wastewater. However, the most dangerous form of nutrient intensifying the process of eutrophication, are their bioavailable mineral forms and their share in treated wastewater discharged into receiver. The aim of the study is to analyse the impact of wastewater treatment technology on the structure of the contents of different forms of nitrogen and phosphorus in treated wastewater in order to determine their eutrophication potential conditioned by the content of bioavailable forms of nutrients. The analysis concerned treated wastewater in modern wastewater treatment plants "Viikinmaki" in Helsinki (Finland) and "Kujawy" in Cracow.

Keywords: municipal wastewater treatment technology, eutrophication potential, bioavailable forms of nitrogen and phosphorus.

DOI:10.7862/rb.2016.167

Przestano do redakcji: 01.05.2016 r.

Przyjęto do druku: 28.06.2016 r. 